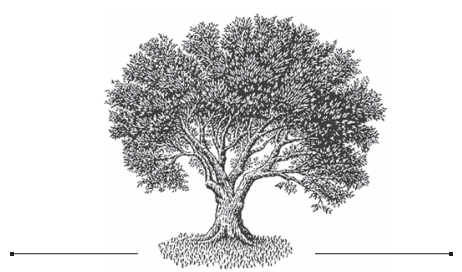

Russian Orthodoxy and Autobiographies in the Early Modern Period from a Mediterranean Perspective $^{*}$

[Rev. of: Faith and Selfhood in a Changing Society: Autobiography and Orthodoxy in Russia from the End of the Seventeenth to the Beginning of the Twentieth Century, ed. Laurie Manchester and Denis A. Sdvizhkov. Moscow: NLO, 2019, 408 pp. (in Russian)]

\section{Relja Seferović}

Croatian Academy of Sciences and Arts Institute for Historical Sciences, Dubrovnik, Republic of Croatia
Русское православие и автобиографии раннего Нового времени в средиземноморской перспективе

[Рец.: Вера и личность в меняющемся обществе. Автобиографика и православие в России конца XVII - начала XX века / Сборник статей; под редакцией $\Lambda$. Манчестер, Д. А. Сдвижкова. М.: Новое литературное обозрение, 2019. 408 с.: ил. (Серия Studia Europaea)]

\section{Реля Сеферович}

Институт исторических наук Хорватской академии наук и искусств, Дубровник, Республика Хорватия

* This paper was funded by the Croatian Science Foundation, as part of the project INTRADA, "Traditionalism and Innovation in Dubrovnik from the Middle Ages until the Nineteenth century", IP-2018-01-5527.

Citation: Seferović R. (2021) Russian Orthodoxy and Autobiographies in the Early Modern Period from a Mediterranean Perspective. Slověne, Vol. 10, № 1, p. 474-486.

Цитирование: Сеферович Р. Русское православие и автобиографии раннего Нового времени в средиземноморской перспективе // Slověne. 2021. Vol. 10, № 1. C. 474-486.

DOI: 10.31168/2305-6754.2021.10.1.22 
Abstract

The collection of papers "Faith and Selfhood in a Changing Society: Autobiography and Orthodoxy in Russia from the End of the Seventeenth to the Beginning of the Twentieth Century" served as a stimulus for reflection on Orthodoxy in Russia and autobiographies as a literary genre at the beginning of the early Modern Age from a Mediterranean point of view. Studying the contributions of fifteen prominent scholars from Russia, Poland, Germany, Canada and the United States on various aspects of the immensely rich Russian spiritual heritage from the mid-17th until the first half of the 20th centuries, the author recognizes their fundamental connection in a sincere interest in the gradual modernization of the Russian society, deeply rooted in the Russian Orthodox faith, as well as in the gradual development of individualism, both in its institutional and non-institutional forms: within the framework of the Russian imperial state and official patriarchal church institutions, but also on the periphery of political movements and religious sects. Despite the relatively narrow area of research devoted to various forms of autobiographies (written mainly by the clergy, less often by the members of secular aristocratic and bourgeois circles), this collection of papers represents not only a carefully written and reliable way to understand one of the fundamental aspects of the Russian spiritual culture, but it also invites for comparison with other similar environments. This prompted the author of the review to make a journey through the parallel literary world of the Republic of Dubrovnik (as the only independent Slavic state in that period, with the exception of the Russian Empire) from the 16th to the 19th centuries, with the conclusion that the predominance of biographies to the detriment of autobiographies in Dubrovnik at that time also speaks of strong pragmatism and aspiration to take care exclusively of the state interests in the literary sphere.

Keywords

Russian Empire, Republic of Dubrovnik, 16th to 20th centuries, autobiographies, spiritual heritage, biographies

\section{Резюме}

Сборник научных статей «Вера и личность в меняющемся обществе. Автобиография и православие в России конца XVII - начала XX века» послужил поводом для размышлений о православии в России и автобиографиях как литературном жанре в начале раннего Нового времени со средиземноморской точки зрения. Изучая работы пятнадцати выдающихся специалистов из России, Польши, Германии, Канады и США по раздичным аспектам богатого русского духовного наследия середины XVII - первой половины XX в., автор признает их фундаментальную взаимосвязь. Она мотивирована искренним интересом к постепенной модернизации российского общества, связанной с русской православной верой, и к постепенному усилению индивидуализма, развивающегося как в институциональной, так и в неинституциональной формах: в рамках российского имперского государства и официальных патриархальных церковных институтов, но также и на периферии политических движений и религиозных сект. Несмотря на относительно узкую область исследований, посвященных раздичным формам автобиографий (написанных в основном высшим духовенством и реже членами светских аристократических и общественных кругов), научные статьи в этом сборнике представляют собой не только тщательно изученный и надежный путь к пониманию одного из фундаментальных аспектов русской духовной культуры, но и подталкивают к сравнению с другими средами. Это побудило автора обзора провести параллель со схожими литературными произведениями 
Республики Дубровник (как единственного тогда независимого славянского государства, за искдючением Российской империи) с XVI по XIX в. Преобладание биографий над автобиографиями в Дубровнике того времени также говорит о сильном прагматизме и стремлении заботиться исключительно о государственных интересах в иитературной сфере.

\section{Ключевые слова}

Российская Империя, Республика Дубровник, XVI-XX вв., автобиографии, духовное наследие, биографии

\section{Through the texts towards an interpretation}

Fifteen prominent scholars from Russia, Poland, Germany, Canada and the United States, experts on various branches of the immense Russian spiritual heritage from the seventeenth to the first half of the twentieth century, joined their efforts in an attempt to discover some of the fundamental changes in Russian religious culture from the source with the apparently narrow perspective: autobiographies. Their approaches are marked by a genuine interest in the gradual modernization of the Russian society, deeply rooted in the Russian Orthodox faith, developed both in its institutional and non-institutional forms: within the framework of the Russian imperial state and official patriarchal Church institutions, but also on the margins of political movements and religious sects. The impetus for their joined work came from the international scholarly conference entitled "The Sacral and the Secular in Autobiographical Practices of the Modern Period (Eighteenth to Early Twentieth Centuries)", that was held at the German Historical Institute in Moscow in June 2016, as part of the research project Церковь говорит ("The Church speaks") ${ }^{1}$.

In their joint preface the editors of this collection of papers, Laurie Manchester (Associate Professor at the Department of History, Arizona State University) and Denis A. Sdvizhkov (Senior Research Associate at the German Historical Institute in Moscow) set out two fundamental ideas that characterise all the contributions presented here: the flexibility of the authors (who did not seek opposites, but rather connections between the various extremes they dealt with) and the idea that the social progress is not limited to secularism and the suppression of the Church. The topics of all the contributions fit into this clearly defined framework, regardless of whether they highlight the narrower issues of language, Canon law, everyday life, Church rites or Early Modern and contemporary ecclesiastical and political history.

Such a complex mosaic required a balanced approach between abundant primary sources (private diaries, letters, chronicles, court reports, synodal and imperial decrees, political pamphlets, to name just a few) and secondary material, developed both in Russia (studies in political and ecclesiastical history, ethnographic studies) and abroad (referring here mostly to autobiographies written by the most famous Western authors from St. Augustine to Voltaire and Rousseau, who greatly influenced the learned Russian public and sometimes served not only as a stimulus, but also as a direct model for

1 https://churchlang.hypotheses.org/1 
autobiographies in Russia). For the readers interested in further research, the editors prepared an exhaustive and meticulously arranged bibliography, which refers to all the texts offered in this collection. This long list consists of published sources and secondary materials, which, in turn, are divided into a group of reference books (indexes and dictionaries) and a separate group of various scholarly papers and conference proceedings, available either in printed form or online.

The papers are arranged in chronological order, according to the topics they are dealing with, while the entire book is notionally divided into three main sections. The first section, entitled "From the Beginning of the Modern Age to the Nineteenth Century", follows the early steps of the formation of individualism and the development of autobiography in Russia. By extolling the Archpriest Avvakum as the author of the first Russian autobiography, Tatiana A. Sochiva (The University of St. Petersburg) perceives Avvakum's "Work of Interpretations and Moralizing” as the corner-stone in the formation of individual self-consciousness in Russia, which strongly affected Russian literature in the second half of the seventeenth century, when the medieval concept of man was finally overcome. ${ }^{2}$ While formally he was writing his autobiography, Avvakum went through an internal controversy: the author quite justifiably claims that the idea of self-sacralization was contrary to his Christian beliefs. Since he was sent into the exile, he lost the opportunity to preach. He subsequently became a writer whose works spread throughout Russia and, in this way, Avvakum also influenced the spread of the idea of writing an autobiography.

On the basis of autobiographical narratives in a broader sense (hagiographies, pilgrimage literature, personal diaries, written confessions) Denis Sdvizhkov examines how the new personality and the new religious culture in Russia appeared in the eighteenth and the early nineteenth century and how this process affected the modernisation of the Russian state. ${ }^{3}$ The new founder of the autobiographical tradition is considered to be St. Dimitry of Rostov, also the first canonized saint of the Russian Church in the synodal era. Thus, he strongly influenced the works of a number of later metropolitans, among whom the autobiography of the Moscow metropolitan Platon Levshin, published an entire century later, stands out. ${ }^{4}$ This announced a number of topics that later works deal with exhaustively: the role of keeping a diary, a description of a pilgrimage, the influence of foreign (Western) writers in Russia, the ignorance of the parish clergy, the role of confession in the individualisation of personality.

With his contribution dedicated to the topic of the hidden tendencies of selfpresentation and individuality among the Russian Orthodox monks during the era of

2 "The Appearance of Individual Consciousness in Russian Literature on the Eve of the Modern Age (Based on a Study of Archpriest Avvakum's 'The Work of Interpretations and Moralizing')", pp. 20-28.

3 "The New Self and New Religiosity in Russian Autobiography from the 18th Century to the first half of the 19th Century”, pp. 29-59.

4 Another observation comes to mind here: by emphasizing that the Moscow metropolitan wrote an autobiography in the third person, the author once again subtly points to connections with Western, classical literature: Caesar (Comments on the Civil War, Comments on the Gallic War) and Augustus (Acts of the Divine Augustus) also left autobiographical records in the third person. 
Emperor Peter the Great, ${ }^{5}$ Gary Marker (State University of New York at Stony Brook) makes the first subtle point on differences between the parish clergy and the monks. While the monks by far surpassed their worldly counterparts (parish clergy) in literacy, they yielded in public activities: silence, inherited from the Byzantine Church, was a typical feature of monastic life. In this period a newly awakened need for the expression and communication had to be sustained through correspondence, and hundreds of preserved letters between monks express a whole range of emotions.

A further step forward towards our understanding of the awakened self-awareness of the Russian clergy in the eighteenth century is the paper by Olga A. Tsapina (Norris Foundation Curator of American History, The Huntington Library, San Marino, CA).${ }^{6}$ On the basis of a lawsuit filed in 1789 by Peter Alekseevich Alekseev, the head of the Kremlin Cathedral of Archangel Michael and the fellow of the Russian Academy, due to his dissatisfaction with the diocesan authorities who refrained from addressing him and his fellow secular priests as "popy" and used the term "presbyters" instead, the author convincingly shows how the Western spirit permeated the Russian Church and strengthened individualism among its members and subjects (even at the cost of rejection of traditional humility). It is natural to observe this unstoppable process of individualization also in the personal notes by prince Ivan M. Dolgorukov (1764-1823), an enlightened courtier who described his own experiences after a pilgrimage to several Russian shrines. ${ }^{7}$ As Alexander M. Feofanov (St. Tikhon's Orthodox University) rightly observes, Dolgorukov's journey becomes a kind of counter-pilgrimage due to his critical remarks on the aesthetics of the liturgy. His vivid descriptions of various practices at different churches he visited demonstrate his gift of observation and offer some precious insights into the religious practices in remote churches, far from major centers. However, while he formally presents himself as a rational, educated man in the Age of Enlightenment, also praising the different kinds of worship such as the Uniate rites, his own good knowledge of Russian Orthodox liturgy and a firm condemnation of any deviation from the usual rules remove his disguise. Prince Dolgorukov shows some signs of interest in ecumenism, but he is still far away from religious tolerance.

Although prince Dolgorukov resented the fact that the double-headed imperial eagle as a symbol of power was placed above the Royal Doors in some of the churches he visited, this was only a small symbol of the supreme secular power over the Church. In her analysis of confessional practice in early nineteenth-century imperial Russia ${ }^{8}$ Nadieszda Kizenko (Department of History, State University of New York at Albany) demonstrates the growing pressure of the state authorities and their distrust of the population since approximately the middle of the seventeenth century, with demands that believers confess as often as possible, thus proving their civic and political loyalty. It is argued that the penetration of Western ideas in the nineteenth century encouraged

5 "Out of the Silences: Charting the Monastic Self in the Long Petrine Era (1680's-1720's)”, pp. 60-88.

6 "Pop and Presbyter: Parity of Ministers, Apostolic Succession and Orthodox Ecclesiastical Identity in Eighteenth-Century Russia”, pp. 89-119.

7 "Faith and Church in the Autobiographical Texts of Prince I. M. Dolgorukov (17641823)", pp. 120-140.

8 "Confession and the Autobiographical Genre in Early 19th Century Russia", pp. 141-160. 
certain women from the highest circles, including court ladies, to accept Catholicism, because it imposed much milder forms of repentance after confession. Earlier strictness is further mitigated by confessions in writing (which is also a privilege only of high circles, especially women), but at the same time the role of mothers in preparing children for the first confession is more emphasized. So-called lifelong confessions become a synonym for autobiographies and the author analyzes them on the concrete example of several prominent members of the Decembrist family Fonvizin, who paid their debt to Rousseau's "Confessions”.

The role of the family as the key micro-structure in society also attracted Galina N. Ulianova (The Institute of Russian History, Russian Academy of Sciences), who scrutinises autobiographical legacies of wealthy merchant families. ${ }^{9}$ In spite of the colorful and vivid descriptions of violence, passionate brawls and altercations typical for members of the lower strata, two key points quickly catch the reader's eye: devotion to regular liturgical practices is the symbol of the entire merchant class and their attendance of liturgical services also serves professional purposes, for gatherings and consultations of purely business nature. Their subsequent rise and intellectual development by the middle of the nineteenth century increased secular habits among the new generations of merchants who discovered other ways to preserve their professional honor, not related to places of the public worship exclusively.

The second large section of this collection, entitled "From the Great Reforms to Revolution", is introduced by the paper written by Laurie Manchester. ${ }^{10}$ The author collects precious information about the life of the parish clergy from printed obituaries, in a period from approximately 1860 until the beginning of the twentieth century. In the gradual modernization of the public life in late imperial Russia the printing press played an increasing role, penetrating more and more into the Church circles as well. This points to two parallel processes of modernisation: technical and social development. With the expansion of printing, the obituaries of Russian Orthodox priests acquire a modern shape. In the local printing houses of the clergy and in the diocesan magazines the published obituaries of the parish clergy included valuable facts about their domestic life, thus abandoning the hagiographic approach typical of older texts and of monasticism.

Another valuable source for this research was singled out by Elena A. Ageeva (Historical museum, Moscow State University Lomonosov), namely, the church chronicles. ${ }^{11}$ Although the initiative for writing church chronicles came simultaneously from the highest State and Church circles (since the invitation of Empress Catherine the Great was later met with a favorable response from the Most Holy Governing Synod), it bore sparse fruit. Expectations that mostly uneducated parish priests, burdened with other duties, would record daily events could not be fulfilled. The chronicles were kept differently in each diocese. Instead of verified news and facts, they often contained

\footnotetext{
9 “Autobiographical Texts by Merchants: Religious Consciousness and Religious Behavior. 1770-1860s”, pp. 161-203.

10 "The Emergence and Meaning of Auto/biographical Practices in Russian Orthodox Parish Clergymen's Obituaries in Late Imperial Russia”, pp. 206-226.

11 "Church Chronicles as a Source for Autobiographical Practice in the Modern Age", pp. 227-244.
} 
unfounded rumors, but their importance is still attested by the fact that they survived in this form in Russian churches in Poland and the Baltic until the 1930s: tradition kept its role.

If, in writing church chronicles, personal observations could not be avoided to the detriment of reliable facts (even to the extent that some chronicles from the area of Perm in the period from 1914 to 1918 did not even mention the First World War), private diaries, just like personal letters, usually offer a real treasure of emotions and rich inner life of individual clerics. Thus, Marta Łukaszewicz (Institute of Russian Studies, University of Warsaw) brought to our attention the curious excerpts of a diary written in 1829-1854 by a rural priest from the diocese of Kiev, the Father Foka Strutinskii. ${ }^{12}$ Although this text is additionally adapted to the interests of a wider audience, due to the efforts of the writer Nikolai Leskov, who transformed it into literature, it still contains original and precious elements of a complex relationship between parish clergy and diocesan bishops, often tainted by the fear of authority, instead of being governed by mutual respect. Reading Father Strutinskii's private diary, Leskov points out the hypocrisy of piety, because the unattractive reality is given the characteristics of a sublime religious event.

Like Father Strutinskii's diary, the diary of Father Mikhail Shcherbakovskii, also from the Kiev diocese, comes from the periphery of the Russian-speaking world. ${ }^{13}$ It is presented by Heather Coleman (Department of History and Classics, University of Alberta), who stresses its manifold importance in the light of his sincere description of personal sufferings after the premature death of his beloved wife, as well as his active involvement in early Ukrainian nationalist movement. Both cases testify to modernisation and the advent of new times: while contemplating the advice of a psychologist to resolve a personal crisis, Father Shcherbakovskii in the first decade of the twentieth century also witnessed the persecution of his sons by the imperial police, on charges of being both Social Democrats and Ukrainian nationalists.

The classical Orthodox environment in the modernisation of late tsarist Russia is also analyzed by Julia Herzberg (Institute of Eastern and South Eastern European History, Ludwig Maximilian University of Munich), who evaluates the contribution of modern media (press) in promoting the moral values. ${ }^{14}$ As the author differentiates three separate "social spaces" in which peasant men recorded their lives (the press and the media, autobiographical projects initiated by scholars, and the family circle), she claims that the flourishing of the Orthodox press since the middle of the nineteenth century played a particularly important role in this. Based on appropriate arguments, this is interpreted as the reaction of the Russian Orthodox Church to the socioeconomic changes in the country and to the growing mass literacy. Publishers perceived their publications as a response to growing criticism of the Orthodox Church from 1850s onwards. Therefore, autobiographies of former serfs, converts and village poets were

12 “The Diary of Priest Foka Strutinskii in Nikolai Leskov's Literary Adaptation (the sketch 'Bishops' Detour')”, pp. 245-265.

13 "Faith, Family, and Nation in the Diary of Kiev-diocese Priest, Father Mikhail Shcherbakovskii”, pp. 266-294.

14 "Parables of the Prodigal Son. Conversion and Faith in Peasant Autobiographies in Late Tsarist Russia”, pp. 295-318. 
often published. It is claimed that the publisher's goal was to reduce the tolerance of Christians towards "heretics" and to point out the differences between the "true" faith and various "heretical" tendencies. In that defensive struggle, Orthodox journalism increasingly revealed its semantic message through the narratives of real or fictional biographies.

Instead of dealing with the lower strata of the society, Gleb M. Zapalsky (Faculty of History, Department of Church History, Moscow State University Lomonosov) $)^{15}$ dedicated his paper to autobiographies written by monks, former noblemen who abandoned their secular life, but still kept many secular habits in their new environment behind the monastery walls. Leaving aside the struggles for power in the monasteries, in which the former nobles often were successful thanks to a better education and stronger social connections compared to their lower-class rivals, the author subtly shows in several carefully chosen autobiographies (written both by monks and by nuns) how the former courtiers and other members of high nobility kept their self-consciousness in the new monastic environment. The break with the previous life usually ended with embittered pages in their autobiographies, lamenting over their difficult fate, and only seldom sincerely trying to bridge the gap between the sacred and the secular.

The final section "An Excursion: after 1917", is a brief digression into the most recent developments, containing only two papers. Alexey L. Beglov (Institute of World History, Russian Academy of Sciences) ${ }^{16}$ deals with the secret monastic communities after the October revolution on the basis of two autobiographical texts written by the leader of the Moscow Vysoko-Petrovsky Monastery (1923-1959), Archbishop Bartholomey (1888-1935). Through a fascinating depiction of secret religious communities made up of young members of both sexes, the author examines events from contemporary church life through the prism of early Christian texts. He rightfully claims that the comparison of modernity with the Biblical history is a traditional method of Christian writing, and in that particular historical context this tradition acquired the new life. Soviet persecutions again actualised the traditional and seemingly lost vitality of the literary procedures of the Christian scriptures, including the autobiographies.

The last paper in this collection is written by Sandra Dahlke (director of the German Historical Institute in Moscow) ${ }^{17}$ Building her work on the comparison of the Bolshevik Emelyan Yaroslavsky (1878-1943) and the Russian Orthodox priest John of Kronstadt (1829-1909), the author concludes that neither the Bolsheviks nor the priests could have been properly shaped without the response of the masses (believers, workers), which gave them and their work the necessary authority. In contact with the masses, they both emphasised their personality in the first place, described their close connection with the masses and reflected on them in writings that highlight their own self, in letters and diaries. The final message of this paper is the thesis that the original individual-emotional determination eventually takes on a politically determined meaning.

15 "The Fates of Monks from the Nobility and their Autobiographical Conceptions", pp. 319-338.

16 "People and History in a Catastrophic Age: Self-Reflexivity among the Leaders of Underground Monastic Communities 1920-1930s", pp. 340-358.

17 "A Bolshevik Construction of Individuality: Performance and Autobiography", pp. 359-383. 


\section{A discourse from the narrow Mediterranean angle}

While reading these texts, an expert in Russian studies will probably have no difficulty in answering to the most of the questions regarding the topics that the authors and the editors dealt with. However, a novice in this area may wonder about the claims of the predominant Western influence in the spread of the autobiographical genre in Russia in general, ${ }^{18}$ more so as the two of the most important figures from the Russian Orthodox Church, the Archpriest Avvakum and St. Dimitry of Rostov, have been singled out as the founders of autobiography in Russia. Despite the certain reliance of St. Dimitry of Rostov on Polish diary-keeping traditions with which he came in touch through Ukrainian literary tradition, neither of them had direct ties to the West. This leaves a room for assumptions about appropriate influences in this field both from the Russian medieval texts and from the Byzantine spiritual heritage as well, although this was not directly pointed out by any author. In addition, the claims of a number of authors that autobiographies primarily encourage individual development and the strengthening of self-awareness, raise questions, such as whether the writers of these autobiographies rejected humility as one of the fundamental Christian virtues.

Although writing autobiographies and personal diaries as lifelong confessions intended for the public can be interpreted as a form of public repentance, did not the authors, by addressing a wide circle of readers, thus build a monument of their own? Is it not the source of the main concern that preoccupied the Archpriest Avvakum as the father of Russian autobiography and, consequently, all of his numerous followers in this fascinating field? If personal identity is affirmed (also) through the communication, why would the communication as a means of self-realization take precedence over the creativity and independent contribution to the whole community in a less publicly prominent field?

A connoisseur of Mediterranean history, on the other hand, should at least appreciate another valuable lesson, viz. that the individual is the key element of change, and, thus, finally overcome the prejudice about Russian society as an amorphous mass. Moreover, he may find a stimulus in these thought-provoking texts for a further research effort through the comparison with some related social phenomena in the Republic of Dubrovnik, a politically independent oasis of the Slavic world in the South, which significantly strengthened its ties with the Russian Empire during the reforms of Peter the Great and Catherine the Great, two rulers during whose reign most of the events discussed here actually took place. ${ }^{19}$

A comparison between these highly distant societies points to several similarities, important in the interpretation of circumstances in which autobiographical writers

18 This approach is also characteristic of the contemporary Croatian literary historians who deal with medieval autobiographies. The traditional origin of the autobiography has been recognized in the influence of Antiquity, but there is also the question of the existence of individuality in the Middle Ages. Therefore the interpretations of the autobiography in a psychological frame set the chronological trinity of Antiquity (consciousness) / the Middle Ages (conscience) / the Modern Period (self-consciousness). On the other hand a genre affinity has been recognized between autobiography, hagiography and biography [Zlatar 2000], [Anđelković 2001].

19 In lack of more modern works, it is necessary to refer to the old syntheses [Foretić $\mathrm{M}$. 2007; Foretić V. 1980: 256-273; Harris 2003: 349-352]. 
in imperial Russia and their contemporaries in the Republic of Dubrovnik lived and worked. ${ }^{20}$ In the case of Dubrovnik there is also firm evidence of the poverty and ignorance of the parish clergy in comparison to friars and monks, according to various decrees by the city archbishops and decisions by diocesan synods, as well as the casual remarks, made both by the local and foreign chroniclers and annalists. However, while the writing of the local church chronicles and annals began in Russia mainly on the initiative of Empress Catherine the Great, the rapid development of Dubrovnik ecclesiastical historiography from the middle of the sixteenth century was mostly influenced by decisions of the Council of Trent (1545-1563) and the subsequent demands by the Popes: especially the members of the Church orders were required to collect all the relevant information on the founding of their religious communities and individual monasteries and to describe their daily routine.

In addition to these demands from the highest Roman circles, a significant role in the development of the domestic ecclesiastical historiography was played by necrologies, which were traditionally kept in monasteries. Together they led to the appearance of a large collections of biographies, which, together with secular annals, formed the backbone of classical Dubrovnik historiography.

Nevertheless, despite a very prolific literary heritage from the observed period (approximately from the end of the seventeenth to the beginning of the nineteenth century), ${ }^{21}$ Dubrovnik cannot boast of a numerous autobiographies. In contrast to the very rich biographical work, which developed especially within the religious orders from the middle of the eighteenth century, ${ }^{22}$ autobiographies are represented only in traces in certain literary attempts. Among them particular attention should be paid to the epic Dubrovnik ponovljen (Dubrovnik restored) by the patrician Jaketa Palmotić (16161680), ${ }^{23}$ a poet and an experienced diplomat who described the torturous travels along the Balkan Peninsula and encounters with Ottoman dignitaries as well as the suffering of his family and entire city in the great earthquake of $1667 .{ }^{24}$ Writing about his own efforts in defense of Dubrovnik's freedom, Palmotić also encouraged the faint spirit of the patricians and the common people, shaken both by the natural disaster and by the

${ }^{20}$ Since the purpose of this text is by no means a detailed analysis of the ecclesiastical or social history of the Republic of Dubrovnik (even in this brief period), only a summary review of the relevant literature has been provided.

${ }^{21}$ The history of Dubrovnik literature has attracted numerous authors since the time of the Dubrovnik Republic, such as Francesco Maria Appendini, a Piarist friar who already in 1803 in his two-volume Notizie istorico-critiche sulle Antichità, Storia e Letteratura de' Ragusei included substantial chapters entitled Sulla letteratura dei Ragusei and Sulla letteratura Slava, o Illirica dei Ragusei [Appendini 1803: 7-315].

${ }_{22}$ The champion of this genre in Dubrovnik was the Dominican friar Seraphinus Maria Cerva (1686-1759), who first wrote biographies of his Dominican brethren and then continued his effort with Bibliotheca Ragusina, a vast collection of more than four hundred biographies of distinguished citizens of Dubrovnik, in four separate volumes [Cerva 1975-1980]. His younger fellow-citizen, Franciscan friar Sebastian Slade Dolci (1699-1777), followed in his footsteps with a similar work entitled Fasti litterarioRagusini [Slade 2001], while the Jesuit Đuro Bašić (1695-1765) gave a significant contribution with Elogia Iesuitarum Ragusinorum, limiting himself, however, only to the members of the Dubrovnik College of the Society of Jesus [Bašić 1933].

${ }^{23}$ His comprehensive contemporary biography is offered by [Vekarić 2013: 66-71].

${ }^{24}$ A new edition has recently been prepared by Slavica Stojan [2014]. 
consequential pressure exerted by the Ottomans and the Venetians along the frontiers of the Republic [Stojan 2014: 24]. Literary critics thus recognized him as "an ideal citizen of Dubrovnik precisely because of his lack of individualism. His text is an autobiography, but from Dubrovnik, and that means harmonious and unobtrusive" [Novak 2003: 101-102; Novak 2004: 155-156].

Less socially engaged was his predecessor, the Benedictine monk Mavro Vetranović (1483-1576), a descendant of a wealthy merchant family of common origins [Plejić-Poje 2016] and an inspired writer whose poems occasionally contain autobiographic elements. This observation is based not only on the poetic form (as most of his poems are written in ich-form) [Plejić-Poje 2007: 123], but also on appropriate content: while in Pjesanca u vrijeme od pošljice (The Poem in the Time of Plague) Vetranović bids farewell to his friends and fellow-monks who perished in the plague epidemic in Dubrovnik in 1527 or 1533, he simultaneously writes an inventory of his own literary work, with a secret message for those informed [Novak 1997: 248-249]. Even more intimate are his lyrical texts written at an advanced age. In the poem Remeta (A Hermit) Vetranović in a tearful tone like an old hermit mourns his life on a lonely island ${ }^{25}$ in the midst of hostile nature, thinking about the ingratitude of people, with a hint of self-irony [Pavličić 2006].

Jaketa Palmotić and Mavro Vetranović stand out as typical examples of Dubrovnik writers of that time, dealing with poetry as the dominant literary genre, and also representing their social strata and professional vocations: Palmotic as a patrician and a professional diplomat, and Vetranović as a commoner and a cleric (monk). Therefore, it is valuable that they incorporated autobiographical elements into their literary works. Similarly to the Russian practice of that time, there were also women in Dubrovnik, both patrician and commoners by birth, who in the late eighteenth century, under the influence of the local preachers, introduced autobiographical elements into their letters addressed to their close family members, sons and brothers [Stojan 1996: 131-135].

Written confessions addressed to high members of the Church were not common; instead, we speak of intimate family records, where just a glimpse of autobiographical features can be discovered. Their rarity speaks in general about the spirit that permeated the educated circles in the Republic of Dubrovnik, both in the secular and in the sacral sphere. Omnipresent pragmatism and the desire to praise the whole city by highlighting individuals resulted in a strong development of writing collections of biographies, instead of more subtle autobiographies.

\section{A look at the conclusion}

As the editors of this collection of papers about autobiography and Orthodoxy in Russia from the end of the seventeenth to the beginning of the twentieth century point out in their joint preface, with the development of personality and the cultural tradition of writing an autobiography, obligation becomes a habit, and a habit becomes an inner need. ${ }^{26}$ It is also a serious lesson to today's man.

25 Vetranović lived for decades almost isolated on the remote island called Sv. Andrija [St. Andrew], located on the high seas a few miles from the city of Dubrovnik, where a priory of the Benedictine Order was established in the early thirteenth century.

${ }^{26}$ L. Manchester and D. Sdvizhkov, "Introduction”, p. 12. 
Through a comparison with the views that marked the daily life of the Republic of Dubrovnik, a small state on the Adriatic Sea, equally threatened by the Ottoman and Venetian claims, we notice how everyday pragmatism penetrated the literary works as well and suppressed the intimate tone in the writing of autobiographies in favor of a widely developed biographical work, praising the state itself through the lives of its distinguished inhabitants. It becomes obvious that the price of centuries of effort to maintain freedom has also been paid by suppressing literary expressiveness.

\section{Bibliography}

Anđelković 2001

Anđelković Lj., Poticajno srednjovjekovlje, Vijenac, 186 (https://www.matica.hr/vijenac/186/ poticajno-srednjovjekovlje-16735/).

Appendini 1803

Appendini F. M, Notizie istorico-critiche sulle Antichità, Storia e Letteratura de' Ragusei, 2, Ragusa [Dubrovnik], 1803.

Bašić 1933

Pavlović D., ed., Elogia Iesuitarum Ragusinorum a patre Georgio Bašić S. J. conscripta, Croatia sacra. Arkiv za crkvenu povijest Hrvata, 3, 1933, 113-216.

Cerva 1975

Cerva S. M., Bibliotheca Ragusina in qua Ragusini scriptores eorumque gesta et scripta recensentur, 1, S. Krasić, ed., Zagreb, 1975. 1977

Cerva S. M., Bibliotheca Ragusina in qua Ragusini scriptores eorumque gesta et scripta recensentur, 2, S. Krasić, ed., Zagreb, 1977.

1980

Cerva S. M., Bibliotheca Ragusina in qua Ragusini scriptores eorumque gesta et scripta recensentur, 3, S. Krasić, ed., Zagreb, 1980.

Foretić M. 2007

Foretić M., Dubrovnik u vrijeme Rusko-turskoga rata (1768-1775) s posebnim obzirom na odnošaje s Austrijom, A. Kisić, ed., Dubrovnik u povijesnim i kulturnim mijenama. Zbornik odabranih radova, Dubrovnik, 2007, 133-198.

Foretić V. 1980

Foretić V., Povijest Dubrovnika do 1808, 2, Dubrovnik, 1980.

Harris 2003

Harris R., Dubrovnik: A History, Zagreb, 2003.

Novak 1997

Novak S. P., Povijest hrvatske književnosti. Od humanističkih početaka do Kašićeve ilirske gramatike 1604, 2, Zagreb, 1997. 2003

Novak S. P., Povijest hrvatske književnosti. Od Baščanske ploče do danas, Zagreb, 2003. 2004

Novak S. P., Povijest hrvatske književnosti, 1: Raspeta domovina, Split, 2004.

Pavličić 2006

Pavličić P., Dva pustinjaka, Čovjek, prostor, vrijeme. Književnoantropološke studije iz hrvatske književnosti, Ž. Benčić, D. Fališevac, eds., Zagreb, 2006, 81-102. 
Plejić-Poje 2007

Plejić-Poje L., Vetranovićeva Orlača riđanka rečeno u blatu ribarom, Narodna umjetnost, 44/2, 2007, 119-134. 2016

Plejić-Poje L., Vetranović, Mavro, Hrvatski biografski leksikon, 2016 (cited according to online edition: https://hbl.lzmk.hr/clanak.aspx?id=11918).

Slade 2001

Slade S., Fasti litterario-Ragusini. Dubrovačka književna kronika, P. Knezović, ed., Zagreb, 2001.

Stojan 1996

Stojan S., Duhovni život dubrovačkih gospođa u 18. stoljeću, Dubrovnik, 3-4, 1996, 120-135. 2014

Stojan S., Dubrovnik ponovljen Jakete Palmotića Dionorića, Zagreb-Dubrovnik, 2014.

Vekarić 2013

Vekarić N., Vlastela grada Dubrovnika, 4: Odabrane biografije (A-D), Zagreb-Dubrovnik, 2013.

Zlatar 2000

Zlatar A., Srednjovjekovna autobiografija. Ispovijest $i$ životopis. Rasprava, Zagreb, 2000.

\section{References}

Cerva S. M., Bibliotheca Ragusina in qua Ragusini scriptores eorumque gesta et scripta recensentur, 1 , S. Krasić, ed., Zagreb, 1975.

Cerva S. M., Bibliotheca Ragusina in qua Ragusini scriptores eorumque gesta et scripta recensentur, 2, S. Krasić, ed., Zagreb, 1977.

Cerva S. M., Bibliotheca Ragusina in qua Ragusini scriptores eorumque gesta et scripta recensentur, 3, S. Krasić, ed., Zagreb, 1980.

Foretić M., Dubrovnik u vrijeme Rusko-turskoga rata (1768-1775) s posebnim obzirom na odnošaje s Austrijom, A. Kisić, ed., Dubrovnik u povijesnim $i$ kulturnim mijenama. Zbornik odabranih radova, Dubrovnik, 2007, 133-198.

Foretić V., Povijest Dubrovnika do 1808, 2, Dubrovnik, 1980 .

Harris R., Dubrovnik: A History, Zagreb, 2003.

Novak S. P., Povijest hrvatske književnosti, 1: Raspeta domovina, Split, 2004.

Novak S. P., Povijest hrvatske književnosti. Od Baščanske ploče do danas, Zagreb, 2003.

Novak S. P., Povijest hrvatske književnosti. Od humanističkih početaka do Kašićeve ilirske gramatike 1604, 2, Zagreb, 1997.

Relja Seferović, dr. sc., znanstveni savjetnik

u Zavodu za povijesne znanosti HAZU u Dubrovniku

20000, Dubrovnik, Lapadska obala 4

Republika Hrvatska / Republic of Croatia

rseferovic@hazu.hr
Pavličić P., Dva pustinjaka, Čovjek, prostor, vrijeme. Književnoantropološke studije iz hrvatske književnosti, Ž. Benčić, D. Fališevac, eds., Zagreb, 2006, 81-102.

Pavlović D., ed., Elogia Iesuitarum Ragusinorum a patre Georgio Bašić S. J. conscripta, Croatia sacra. Arkiv za crkvenu povijest Hrvata, 3, 1933, 113-216.

Plejić-Poje L., Vetranović, Mavro, Hrvatski biografski leksikon, 2016.

Plejić-Poje L., Vetranovićeva Orlača riđanka rečeno u blatu ribarom, Narodna umjetnost, 44/2, 2007, 119-134.

Slade S., Fasti litterario-Ragusini. Dubrovačka književna kronika, P. Knezović, ed., Zagreb, 2001.

Stojan S., Dubrovnik ponovljen Jakete Palmotića Dionorića, Zagreb-Dubrovnik, 2014.

Stojan S., Duhovni život dubrovačkih gospođa u 18. stoljeću, Dubrovnik, 3-4, 1996, 120-135.

Vekarić N., Vlastela grada Dubrovnika, 4: Odabrane biografije $(A-D)$, Zagreb-Dubrovnik, 2013.

Zlatar A., Srednjovjekovna autobiografija. Ispovijest $i$ životopis. Rasprava, Zagreb, 2000. 